\title{
The Slowdown in Health Care Spending in 2009-2011 Reflected Factors Other Than the Weak Economy and Thus May Persist
}

\section{Citation}

Ryu, Alexander. 2016. The Slowdown in Health Care Spending in 2009-2011 Reflected Factors Other Than the Weak Economy and Thus May Persist. Doctoral dissertation, Harvard Medical School.

\section{Permanent link}

http://nrs.harvard.edu/urn-3:HUL.InstRepos:40620282

\section{Terms of Use}

This article was downloaded from Harvard University's DASH repository, and is made available under the terms and conditions applicable to Other Posted Material, as set forth at http:// nrs.harvard.edu/urn-3:HUL.InstRepos:dash.current.terms-of-use\#LAA

\section{Share Your Story}

The Harvard community has made this article openly available. Please share how this access benefits you. Submit a story. 
Scholarly Report submitted in partial fulfillment of the MD Degree at Harvard Medical School

Date: 1 March 2016

Student Name: Alexander Ryu, BA, Economics

Scholarly Report Title: The Slowdown In Health Care Spending In 2009-11 Reflected Factors Other Than The Weak Economy And Thus May Persist

Mentor Name(s) and Affiliations: Michael E. Chernew, PhD, Department of Health Care Policy, Harvard Medical School

Collaborators, with Affiliations: Teresa B. Gibson, PhD, Department of Health Care Policy, Harvard Medical School; M. Richard McKellar, MHSA, Department of Health Care Policy, Harvard Medical School 


\section{$\underline{\text { Abstract }}$ \\ Title: The Slowdown In Health Care Spending In 2009-11 Reflected Factors Other Than The Weak Economy And Thus May Persist}

Alexander J. Ryu, Teresa B. Gibson, M. Richard McKellar, Michael E. Chernew

Purpose: In the years during and following the Great Recession, US healthcare spending grew at historically low rates. There has been tremendous debate over whether US healthcare spending will continue growing at these low rates or revert to a higher mean level of growth. This projection of growth rates has important implications for national budgeting. We sought to determine whether low rates of spending growth are likely to persist.

Methods: We used the 2007-11 Truven Health MarketScan Commercial Claims and Encounters Research Databases as well as 2006-2011 National Health Expenditure Accounts data to perform three analyses. First, we compared per-enrollee spending among the privately insured to overall per capita spending to understand how loss of insurance and slower spending growth by the insured affected overall spending growth rates. Second, we examined the growth in out-ofpocket (OOP) spending on ED and outpatient visits, admissions, and brand-name drugs by the privately insured, to understand which types of OOP payments affected spending growth. Finally, we examined spending growth by the privately insured adjusting for OOP payments and compared that to unadjusted spending growth to understand the overall effect of rising OOP on spending growth.

Results: Relative to per capita national health expenditures, per-enrollee spending among the privately insured grew faster 2008-2009, but slower in 2010-2011. Depending on the service, OOP payments grew 20-65 percent cumulatively from 2007-2011. Rising OOP payments accounted for roughly 20 percent of the slowdown in spending growth among the privately insured following the Great Recession.

Conclusions: The spending slowdown following the Great Recession does not appear to be fully accounted for by loss of insurance or increasing OOP expenditures, despite large OOP increases. This suggests that fundamental changes in healthcare practice, rather than temporary recession effects, may underlie the observed slowdown. 


\section{Description of contribution}

For this project, I first drafted a grant for the Robert Wood Johnson Foundation (RWJF) using study objectives that were brainstormed by Dr. Chernew and me independently, and then combined. The grant draft was lightly revised with input from Dr. Chernew and Dr. Gibson. After receiving grant approval from RWJF, I developed a plan for analysis, which I refined with input from Dr. Chernew. Subsequently, with input from Dr. Chernew and I, Rick McKellar prepared a cleaned, 10 percent sample of the Marketscan data for model testing. With this, I developed, tested, and refined our models using STATA with troubleshooting help from Rick and Dr. Chernew. I then ran these models on the full data set with technical assistance from Rick and subsequently reformatted and organized the Excel output into useful charts and statistics. I drafted the final manuscript and directed several rounds of revisions between Dr. Chernew and me, and later with the Health Affairs editors.

The final manuscript may be found here:

http://content.healthaffairs.org/content/32/5/835.abstract 